\title{
EUROPEAN SOCIETY FOR PEDIATRIC RESEARCH
}

\begin{tabular}{cclc}
\multicolumn{2}{c}{ Abstracts for the 1989 Annual Meeting, June $11-14$, Kraków, Poland } \\
\multicolumn{2}{c}{ ESPR Council Members } & \multicolumn{1}{c}{ Local Organizing } & Committee \\
TREASURER & J. Pietrzyk & G. Lis \\
PRESIDENT & U. Wiesmann & Z. Mitkowska & J. Molicki \\
J. Pietrzyk & MEMBERS & J. Lankosz-Lauterbach & J. Nowak \\
PAST PRESIDENT & D. Molnar & W. Borkowski & B. Pawlicki \\
S. Halvorsen & J. Micheli & E. Cichocka-Jarosz & B. Rózanski \\
PRESIDENT 1990 & O. Saugstad & A. Czarnowieska & M. Sanak \\
K. Widhalm & E. Galli & J. Domański & E. Starzycka \\
SECRETARY & EX-OFFICIO & B. Heretyk & M. Stepień \\
A. Okken & K. Raivio & A. Janik & K. Strózik \\
& & O. Karasińska & T. Szczerbiński \\
& & M. Kolaczkowska & J. Szydlowska \\
& & E. Kostyk & A. Żebrowska
\end{tabular}

CEREBRAL AUTOREGULATION IN PRETERM INFANTS. Margot van de Bor, Frans J. Walther, and Maureen E. Sims. University of Southern Calffornia, School of Medicine. Dept. of Pediatrics, Los Angeles, California, USA.

Cerebral autoregulation has been demonstrated in newborn animals. We studied the relationship between gean arterial pressure (MAP) and cerebral blood flow velocity (CDFV) in 90 stable preterm infants $\leqslant 32$ weeks gestation.
Mean (SD) gestational age was $28.9(1.9)$ wks, birth weight 1,128 (230) grans, 5 min Apgar score $7.4(0.9)$, and initial pH $7.36(.08)$. All infants had been normoxic and normocarbic from birth onwards. Intracranial hemorthage and patent ductus arteriosus were excluded. CBFV was determined at MAPs ranging from 27-50 Hg. Using 2-D/ Doppler ultrasound, we obtained CBFV waveforms from the perfcallosal $(P C A)$, internal carotid (ICA), and basilar (BA) arteries between 12-72 hours of age. Peak systolic, end diastolic, and mean (MFV) flow veloctities were derived from 3 consecutive cardiac cycles.

A linear relationship between MAP and MFV was found in all 3 arteries: $r=76$ in the PCA, $r=.73$ in the ICA, and $r=.70$ in the $B A$ $(p<.001)$. Multiple regression analysis showed that the MFV was solely determined by MAP and not by $\mathrm{PaCO}, \mathrm{PaO2}$, heart rate or mean airway pressure.

We conclude that between $27-50 \mathrm{~mm}$ Hg MAP a linear relationship between MAP and MFV exists in 3 major intractanial arteries. These data raise questions about the ability of the very pretern infant to regulate cerebral blood flow.

DYSEIBRINOGENEMIA IN BURNED CHILDREN.Domenico Del Principe, Adriana Meniche11i, Massimo Giordani, Carlo M. 2 Colucci,Claudio Colistra,Stefano Di Giulio.Dept.of Public Health, University"Tor Vergata", Rome, Italy. Severely burned children often show a dysfunction of microcirculation, due to overproduction of $\mathrm{O}_{2}$ radicals and to the activation of blood coagulation. Ne studied the effect of $\mathrm{H}_{2} \mathrm{O}_{2}$ on fibrinogen collected from burned children. Controls were healthy aduit donors. Fibrinogen was purified through precipitation with PEG and saltin-out procedure. The thrombin-induced transformation of fibrinogen to fibrin,as assayed by recording the polymerization curves, was faster in the patient native fibrinogen than in controls $(n=18, p<0.001)$. The oxidacion of control fibrinogen with $\mathrm{H}_{2} \mathrm{O}_{2}$ caused a decrease of the structurally reactive protein (measured by a nephelometric method) and increased the velocity of fibrinogen-fibrin transformation. It was also associated to a decrease of thryptophane residues, as assayed by the spectral changes at $282 \mathrm{~nm}$.At the same experimental conditions,similar changes were not observed in patient fibrinogen. Patient fibrinogen showed a decreased number of aminoacid residues reactive to the"in vitro" oxidation.Our data demonstrate the existence of some structural differences between patient and normal fibrinogen, that may be relevant in the pathophysiologic events following burns.
OXYGEN RADICALS PLAY A ROLE IN THE PATHOGENESIS OF 3 ANAPHYLACTOID PURPURA(AP). Adriana Menichelli, Giovanna Rosati, Daniela Orsini, Domenico del Principe.Dept.of Public Health, University"Tor Vergata", Rome, Italy.

Ceruloplasmin(CPM) was measured by an immunologic nethod in sera of children with AP during the acute phase of the disease, and the values were compared to that estimated by measuring serum ferroxidase activity.Controls were healthy adults. In agreement with previous observations, more copper-containing protein was present in the serum of AP patients than in control serum( $43.4 \pm 12$ vs $31.7 \neq 7.3$ $\mathrm{n}=12, \mathrm{p}=0.016$ by Student's $t$ test). In control sera the same atrount of CPM, measured either by immunologic or enzymatic method, was detected.CPM values of AP. patients,assayed as ferroxidase activity, were,instead,significantly lower than it would be expected on the basis of CPM protein found ( $p<0.001$ by Student's paired $t$ test). However values were well correlated with the amount of CPM immunologically determined $(r=0.97 i, p<0.001)$ suggesting for the presence of an abnormal protein. Our results indicate a critical role for oxidizing species in the pathogenesis of AP, since the discrepance between the protein amount and its enzyme activity is a marker of "in vivo"presence of oxygen radicals.

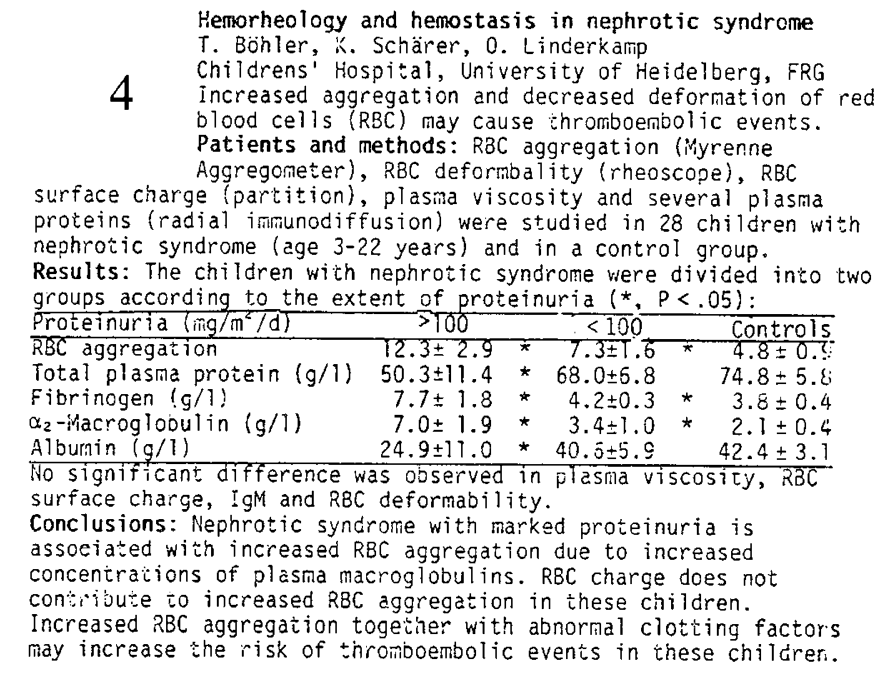

